\title{
The Research and Application of Art Price Index
}

\author{
Danting Chang \\ School of Finance \\ Shanghai University of Finance and Economics \\ Shanghai, China \\ changdanting@126.com, casting82@126.com
}

\begin{abstract}
Art price index is an important reference for art investment. Art price index calculated by using a similar method of stock price index can't reflect the actual art market situation because of their different trading mode. The application literature reports about calculating art price index by using econometric models have been summarized and analyzed in this paper. Several art price indexes commonly used and their characteristics and application have also been summarized and analyzed. It has been putted forward for the future research directions about domestic art price assessment.
\end{abstract}

Keywords- art; price index; econometric model

\section{INTRODUCTION}

In recently years, more and more people pay attention to art investment. As an investment asset, return and risk are important purchasing criteria. The research on art investment return and price assessment becomes a key academic study branch in investment field.

As stock index, art price index is an important parameter reflecting the overall price level of art market. Same as the stock index calculation, average price method is originally used calculating art price index. The art price index first launched by Sotheby's was based on this average price method.

Art price index calculated by average price model can not reflect the true art market situation because of the longer transaction interval, non-continuous auction, complex auction environment and places, and art uniqueness. Therefore, the repeat sales regression model (RSR) and hedonic regression model have been used to calculate art price index and return in the late 1980s.

Historical transaction data are necessary for calculating art price index and return. There are a lot of transaction data about western art market because of long time developing, which lay the foundation for art price index research. Researches on art price index and return mostly are based on auction transaction data of paintings in Europe and the United States market, because there is a large quantity of paintings preserved, which account for the largest share in art market, and there are clear categories.

Art transaction data used for research are mostly based on auction transaction data of auction companies. The auction data about mainstream art can be traced back to eighteenth century in European and American, when art auction companies began to emerge. The security market in developed countries had formed in the late eighteenth century, which has recorded the securities market information in detail. Therefore, we can compare art market price index and return with the stock and bond markets during the same period.

In the first part of this paper, application literature reports about calculating art price index by using econometric models have been summarized and analyzed, and several art price indexes commonly used overseas and their characteristics and application have also been summarized and analyzed. In the second part, researches on domestic art price index and its application have been summarized and analyzed. In the third part, it has been putted forward for the future research directions about domestic art price assessment.

\section{RESEARCHES ON ART PRICE INDEX OVERSEAS}

\section{A. Related Studies by RSR Model}

The basic mathematical expression of RSR model for calculating art price index is:

ri $=\ln ($ pi,s/pi,b $)=X \mu+\xi i \quad i=1,2,3, \ldots N$

where ri denotes the logarithm of art return on investment art $\mathrm{i}, \mathrm{i}=1,2,3, \ldots \mathrm{N}$ represents $\mathrm{N}$ data pair, pi,b and pi,s express buying price and selling price of the art $i$ respectively. Divide the research time interval into a series of period $\mathrm{t}=1,2,3, \cdots \mathrm{T}, \mathrm{X}$ is dummy variable matrix with dimension $(\mathrm{N} \times \mathrm{T}$ ), its value is 1 when selling (when the art $\mathrm{i}$ is bought at the time bi, and sold at the time si, $\mathrm{Xi}, \mathrm{j}=1$, where $\mathrm{bi}<\mathrm{j} \leqq \mathrm{si})$, others are $0 . \mu=(\mu 1, \mu 2, \mu 3, \ldots$ $\mu \mathrm{t}, \ldots \mu \mathrm{T}$ ) is logarithm of return on investment portfolio, which is used to estimate the art price index. $\xi \mathrm{i}$ is the function of error.

RSR model was first used to estimated return on painting by Baumol in 1986[1]. His analysis results show that the average annual return on painting investment was about $0.55 \%$ by analyzing 640 pair repeat sale auction prices from 1652 to 1961(data from the book "The economics of taste: the rise and fall of picture prices, 17601960 written by Gerald Reitlinger), that was lower than UK bond yields in the same period (about 2.5\%).

RSR model was used to estimate a semiannual price index for modern prints by Pesando in 1993[2]. He collected 27961 pair auction prices for repeating sale of 28 artists' 
modern prints in European and American market for the period 1977-1992(data from “Gordon' Print Price Annual"). The analysis results show that the semiannual price index was on the rise before 1990, down slightly during 19811982, rising fast in 1985, reaching high spot until 1990, then fall rapidly. The annual return was about $1.51 \%$ that was lower than the yields of American stock and bonds during the same period. Therefore, the fluctuation of art return was roughly the same as stock and bond, which means that there was a little bigger risk on art investment. The deviation analysis results show that the semiannual price index reflects the actual return well.

Goetzmann had collected 3329 pair auction prices for repeating sale of 2809 European and American paintings from 1715 to 1986 (data from the book "The economics of taste: the rise and fall of picture prices, 1760-1960" written by Gerald Reitlinger and "International Auction Records" from 1971 to 1989 written by Enrique Mayer)[3]. RSR model was used to analyze art price index. The results show that art market had three obvious bull markets and bear markets, and the three bull markets time coincided to the price inflation of consumer goods in Britain and the United States, furthermore there was economic depression in British and the United States in the same period of three bear markets. Art price index associated highly with the stocks and bonds of London during the same period and art return significantly higher than stock and bond yield from 1850 .

Art auction price was affected by many factors even for the same art. Taking the auction company and painting catalogues into consideration, Mei and Moses collected 4896 pair auction price just auctioned in the New York main hall of Sotheby and Christie during 1875-2000(data mainly from the New York Public Library and the Watson Library at the Metropolitan Museum of Art), which fall into three categories: 899 pair for American painting works (mainly created in 1700-1950), 1709 pair for the Impressionist Works (mainly created in the late nineteenth Century to twentieth Century), and 2288 pairs for classical painting works (mainly from twelfth Century later to nineteenth Century)[4].RSR model and three stages least variance method regression analysis were used to calculate the composite annual price index, annual price index, and the actual annual return and deviation (total average during 1985-1999, a century average from 1900 to 1999, a half century average from 1950 to 1999). The results showed that several big fluctuations of art price index conformed to the art bull market and bear market recorded by art market, and art price decrease during oil crisis in 1974-1975 and economic recession from 1929 to 1934. The calculated actual art annual return (error $0.2 \% \sim 0.3 \%$ ) was lower than the United States stock return in the same period, but higher than the fixed bond return. The relevant calculation results showed that art price index was barely relevant with stocks and bonds. The risk analysis results showed that systemic risk of art investment was smaller than that of stock, and greater than that of fixed income bonds, which fit the positive correlation of income and risk for financial investment. This paper also compared the results with that of Pesando and Goetzmann, and deemed that the different results were mainly due to the sample sources or classes.

The calculated art price index by RSR model reflects the art portfolio yield better. In addition, as long as the samples are the same, the calculated results are repeatable, and have high reliability, but the single art must have at least two auction records during the study period that such available data are very few, which causes the application of RSR model in art price index study is limited.

\section{B. Related Studies by Hedonic Regression Model}

Hedonic regression model takes into account the effect of a series of art characteristics on art price, such as the artist's features (name, age, born and death), art characteristics (size, medium etc.), auction details (auction companies, seasonal, year) [5-7].

The basic mathematical expression of Hedonic regression model for calculating art price index is:

$\operatorname{lnp}_{i t}=\sum_{k=1}^{m} \alpha_{k} x_{i k t}+\sum^{\mathrm{n}} \sum_{t=1}^{T} \beta_{t} y_{i t}+\varepsilon_{i t}, i=1,2,3 \ldots \ldots . N$

Where pit is the price (sample data) of the art $\mathrm{i}$ at time $\mathrm{t}$, $\mathrm{m}$ denotes the art has $\mathrm{m}$ quantitative variables $\mathrm{k}$, xikt represents the value of quantitative variables $k$ of the art $i$ at time $\mathrm{t}, \alpha \mathrm{k}$ represents the influence coefficient of variables $\mathrm{k}$, $\mathrm{T}$ denotes the research period includes $\mathrm{T}$ time interval, $\mathrm{n}$ represents $n$ qualitative variables, yit is the value of qualitative variables $n$, regarded as time dummy variable, taking 1 or 0 . yit $=1$ denotes the qualitative variable $n$ has effect on art $\mathrm{i}$ at $\mathrm{t}$, yit $=1$ represents the qualitative variable $\mathrm{n}$ has no effect on art $i$ at $t . \beta$ is the art price index at $t, \varepsilon$ it is the error function with mean value 0 . $i=1,2,3, \ldots \mathrm{N}$ represents $\mathrm{N}$ sample data records.

The effects of art characteristics on price can be estimated separately using Hedonic regression model by regressive analysis and all transaction data records in the study time interval can be used. The relative research results show that art price is closely related to a series of art characteristics indeed, such as artist, painting size, pigment, auction houses, and auction season et al $[5,6]$.

Oliver Chanel calculated the art price index using Hedonic regression model according to 25300 auction records of 82 world famous artist's paintings during 19631993 (records including paintings author, size, appearance, auction place and fake or not, $81 \%$ of auction occurred in the United States, Britain, Japan, France)[7]. The results show that there is a relationship between art market and financial markets, and the impact of financial markets on art market will be delayed for a year or so.

By using Hedonic regression model, Roman Kraeussl and Robin Logher estimated that the art annual return were Russia $10 \%$, China $5.7 \%$, India $42.2 \%$, and the influence coefficient of painter reputation, painting media, decorator, size, auction company had also been estimated according to 24524 Russia paintings during 1985-2008, 7172 Chinese paintings during 1990-2008, 2858 Indian paintings during 2002-2008[8]. Dougles J.Hodgson and Keith P.Vorkink 
studied Canadian paintings market using Hedonic regression model by analyzing the 13000 auction records (including auction price, auction house, artist, painting size, medium, decorator etc)[9]. He estimated the prospective price and return, and ranked Canadian painters by paintings prospective value. Bocart.F and Oosterlinck studied the impact of fake on art market using Hedonic regression model, and the results show that the exposure of fake does not affect art auction volume and art price immediately, the soar of art prices easily lead to the emergence of fake, and art price will reduce after 136 days of fake exposed, but the art price begin to rise a year later [10].

The repeatability of analysis results is low by Hedonic regression model because the results depend on the model variables that will be different due to the set method even for the same sample. The coefficient of variables on art price may change along with time, which had not been considered in above studies. Failure auction may also affect art price that had not been considered by both RSR and Hedonic regression model.

\section{Related studies by Modified Model}

Modified models have been putted out base on RSR and Hedonic regression model that are used to analyze the recent art market with the results more actual.

Base on Hedonic regression model, Heckman's two stage method was used by Alan Collins et al to estimate art price index by considering the impact of failure auction proportion on art price, the analysis results was more close to actual [11].

A hybrid model has been proposed by Locatelli Biey M. and Zanola R. that combined RSR with Hedonic regression model, and the results show that the confidence interval of art price index is compact[12]. RSR, Hedonic regression model and Hybrid model were used by Dominic Taylor and Les Colemanto to estimate art price index by analyzing 4360 paintings auction data of 50 Australian indigenous artists in 1982-2007, of which one-time auction data was 4234, repeat sale data pair was 63[13]. The results show that the art price index calculated by using RSR model was unrepresentative because of the less sample data, and the art price index calculated by using Hedonic regression model and Hybrid model was basically the same.

A heteroscedastic hedonic regression model has been proposed by Fabian Y.R.P.Bocart and Christian M.Hafner, which mainly consider the change of coefficient with time [14]. The concept of fluctuations for predicting art price has been put forward in addition to estimate art price index by analyzing 5621 painting auction data of top 100 blue-chip artist from 2005 January to 2010 June. The results show that fluctuations for predicting art price decreased along with the increase of coefficient fluctuation, and vice versa, furthermore, it was the same as the fluctuations of standard $\&$ poor's 500 indexes. The fluctuations for predicting art price should be referenced when buying single art and art price index should be referenced when investment on art portfolio.

\section{Overseas Art Price Index}

The most commonly used art price indexes are Sotheby's Art Index, all kinds of AMR Art Indexes researched by Britain's top consulting company "Art Market Research", all kinds of Artprice Globle Indexes published by "the global art market information network Artprice.com", Mei Moses Art Index etc.

The calculation methods of art price index published by the three big companies are commercial secrets. Average price model was first used to estimate art price index by Sotheby, which had been eliminated.

Mei Moses Art Index was founded in 2003 as analyzed in section II.A of this paper. Mei Moses Art Index database has been extended. It has been more than 8000 data, and is updated and follows index tracking every year [15, 16]. Mei Moses Art Index has taken attention of large western investment agencies, and the top financial institutions, such as Barkley bank which have adopted the Mei Mose Art Index for art investment analysis. The well-known investment bank Morgan Stanley regards Mei Moses Art Index as one of the world's ten major indexes.

\section{RESEARCHES ON ART PRICE INDEX DOMESTIC}

\section{A. Related Studies}

There are little reports about estimating art price index about China art markets by using RSR model because of the poor repeat sale data because China art market started relatively late. Overseas research results about painting art price index laid the foundation for analyzing China art markets.

Hedonic regression model has been used by Wang Yi to study china painting market by analyzing the paintings auction records of 36 Chinese painters, 22 oil painters provided by Artron.net during 2000 spring -2009 autumn, a total of 16 characteristics variables were selected such as paintings area, GDP in China when trading begins, painting materials, decorators, auction seasons, auction places, creation time, sign or not etc [17]. The characteristics coefficients on painting price have been given in the results. Hedonic regression model has been used by Ma Lina to study china painting market by analyzing paintings auction records of the top 22 Chinese painters, 41 oil painters provided by Artron.net during 2000-2009, characteristics such as artist name, life and death, painting size, creation time, sign or not, painting materials, auction house and auction season were selected (a total of 61 variables about oil paintings, a total of 38 variables about Chinese traditional paintings) [18]. The change of characteristics coefficients with time has been considered in this paper. According to the total auction volume of artist's paintings, price, the first transaction time, lu Xiaohong collected auction records of the most representative 12 Chinese traditional painters and 16 oil painters from 1992 to May 2006 auctioned by the domestic 8 auction companies provided by Artron.net, 7 factors such as art size, creation time, auction house, selling time, exhibition number, materials (such as: Chinese traditional painting, oil painting etc), subject (such as: figure, scenery etc) were selected combined with the specific circumstances of China painting 
and auction market. Hedonic regression model that is suitable for Contemporary Chinese traditional painting and oil painting has been established, and the characteristics price index are calculated, which can be used to forecast the prospective transaction price [19].

\section{B. Domestic Art Price Index}

The most important domestic art market indexes are "Artron index" (AAMI) and "Art index" (AMI) at present.

"Artron index" is published by Shenzhen Artron net, according to the art transaction data auction in all important auction companies in mainland and Hongkong from 1993 to now in "Chinese art market auction database". It covers artist's art price index and all kinds of comprehensive indexes such as 400 component indexes of traditional Chinese paintings, 100 component indexes of oil paintings and the classification indexes etc. Artron index are calculated by using the average price model [20].

There are two questions about the calculation method of "Artron index", one is that the art size as the basic unit price index is worth pondering, the other is that it ignores the impact of quality and fake on transaction price, which should cause artist index distortion when a fake has been auctioned or individual boutique art is launched.

"Art index" full name is "dynamic index system of Chinese art market AMI" (the Art Market Index), created by art index monitoring survey center, and including art market index and the composition art index. The samples of composition art indexes are representative in both artist and paintings auctioned, and the auction data mainly come from auction house, gallery and art fair, starting at September 30, 2003.

The AMI are calculated by weighted arithmetic mean method which takes the art size as the influence of the weight. The samples of composition art indexes are being adjusted, with $10 \%$ before and after $10 \%$ eliminate from master samples according to unit transaction price during current period, remaining $80 \%$ into the calculation range. The influence of the art quality (good, common, bad), content (landscape, figures, flowers and birds etc), transaction forms (auction, gallery etc) on art price are also considered [21].

\section{SUMMARIES}

Scientific investment return analysis and risk assessment is necessary for healthy development of art market. The research on art price assessment theory in domestic has just started, and there is a lot of work to do. Some directions are proposed, such as constructing profit analysis model suitable for different art portfolio, establishing multiple art indexes by using econometric models, the correlation analysis of art investment return with stock and bonds, the comparative analysis of domestic art investment return to international art investment return, in order to provide scientific theoretical supports for art investment in China.

\section{REFERENCES}

[1] William J.Baumol, "Unnatural value: or art investment as floating crap game," The Americann Economic Review, 1986, 76(2):pp.1014.

[2] James E. Pesando, "Art as an investment: the market for modern prints," The Americann Economic Review, 1993, 83(5): pp1075-1089.

[3] William N.Goetzmann, "Accounting for taste: art and the financial markets over three centuries," The Americann Economic Review, 1993,83(5):pp1370-1376.

[4] Jianping Mei and Michanel Moses, "Art as an investment and the underperformance of masterpieces," The American Economic Review, 2002,92(5): pp1656-1668.

[5] Helen Higgs and Andrew Worthington, "Financial returns and price determinants in the Australian art market, 1973-2003," The Economic Record, 2005(81), pp113-123.

[6] Richard J. Agnello and Renee K. Pierce, "Financial returns, price determinants, and genre effects in Americann art investment," Journal of Cultural Economics, 1996(20), pp359-383.

[7] Oliver Chanel, "Is art market behavior predictable," European Economic Review, 1995 (39): pp519-527.

[8] Roman Kraeussl and Robin Logher, Emerging art markets [J], Emerging Markets Review, 2011(11):p301-318

[9] Dougles J.Hodgson and Keith P.Vorkink, "Asset pricing theory and the valuation of Canadian paintings," The Canadian Journal of Economics, 2004,37(3): pp629-655.

[10] Bocart.F and Oosterlinck.K, "Discoveries of fakes: their impact on the art market," Economics Letters, 2011, 113(2):pp124-126.

[11] Alan Collins, Antonello Scorcu and Roberto Zanola, "Reconsidering hehonic art price indexes," Economics Letters, 2009,104(2): pp57-60.

[12] Locatelli Biey M. and Zanola R., "The market for Picasso prints: A hybrid model approach," Journal of Cultural Economics, 2005(29): pp127-136.

[13] Dominic Taylor and Les Coleman, "Price determinants of aboriginal art, and its role as an alternative asset class," Journal of Banking\&Finance, 2011(35), pp1519-1529.

[14] Fabian Y.R.P.Bocart, Christian M.Hafner, "Econometric analysis of volatile art markets," Computational Statistics and Data Analysis, 2012(56):p3091-3104

[15] Mei, Jianping and Michanel Moses, "Vested interest and biased price estimates: evidence from an auction market," Journal of Finance, 2005, 60(5): pp2409-2435.

[16] Mei Jianping, Michanel Moses and Cao Yingxue, "low return on investment famous paintings" Journal of Finance (in Chinese), 2005(8): pp84-88.

[17] Wang Yi, "Research pricing system in painting art," The PhD Thesis of Chinese National Academy of Arts (in Chinese), 2010.

[18] Ma Lina, "Research pricing system in Chinese painting art based on the hedonic model," The Master's Thesis of North China University of Technology (in Chinese), 2011.

[19] Lu Xiaohong, "The research on the hedonic price of contemporary Chinese artwork," The PhD Thesis of Nanjing University of Aeronautics and Astronautics (in Chinese), 2009.

[20] Wang Xiaoyuan, "The research and establishment of Chinese art auction data base and the market quotation index," Shenzhen Science\&Technology (in Chinese), 2005(11): pp56-59.

[21] Song Wen, "The calculation of the art index "the current period quotation of sample Art"," Art Market (in Chinese), 2004 (6):pp1415. 